\title{
PENINGKATAN PEMAHAMAN KONSEP MATEMATIS MELALUI PENGGUNAAN MEDIA KANTONG BERGAMBAR PADA MATERI PERKALIAN BILANGAN DI KELAS II SEKOLAH DASAR
}

\author{
Budi Febriyanto ${ }^{1)}$ Yuyun Dwi Haryanti ${ }^{2)}$ Oom Komalasari ${ }^{3)}$ \\ budifebriyanto88@gmail.com ${ }^{1)}$ yuyundwiharyanti18@gmail.com ${ }^{2)}$ \\ Universitas Majalengka
}

\begin{abstract}
ABSTRAK
Penelitian ini di latar belakangi oleh rendahnya pemahaman konsep matematis siswa yang disebabkan karena proses pembelajaran yang belum mengoptimalkan penggunaan media dalam memahami konsep materi pembelajaran serta belum memberikan kesempatan siswa dalam berpartisipasi aktif dalam proses pembelajaran. Penelitian ini merupakan Penelitian ini bertujuan untuk meningkatkan pemahaman konsep matematis siswa. Subjek penelitian adalah siswa kelas II SDN Simpeureum I sebanyak 30 siswa terdiri dari 14 siswa laki-laki dan 16 siswa perempuan. Teknik pengumpulan data yang digunakan berupa tes dan nontes. Tes terdiri dari butir soal dan nontes terdiri dari observasi, wawancara, dan dokumentasi. Teknik analisis data yang digunakan adalah analisis deskriptif kualitatif untuk menganalisis hasil observasi setiap siklus dan analisis deskriftif kuantitatif untuk menganalisis hasil penilaian pemahaman konsep matematis akhir siswa setiap siklus. Penelitian ini dilakukan dalam tiga siklus. Hasil penelitian menunjukkan bahwa penggunaan media kantong bergambar dapat meningkatkan pemahaman konsep matematis siswa kelas II SDN Simpeureum I. Hal ini ditunjukkan dengan adanya peningkatan ketuntasan belajar siswa dari siklus pertama sampai siklus ketiga. Pada siklus pertama tingkat ketuntasan siswa mencapai $40 \%$, siklus kedua meningkat menjadi $66,67 \%$ dan pada siklus ketiga meningkat menjadi $80 \%$. Kriteria ketuntasan dalam penelitian ini adalah $75 \%$ sehingga dapat disimpulkan penggunaan media kantong bergambar dapat meningkatkan pemahaman konsep matematis siswa kelas II SDN Simpeureum I.
\end{abstract}

Kata Kunci: media kantong bergambar, pemahaman konsep matematis 


\section{Pendahuluan}

Proses pembelajaran pada mata pelajaran matematika masih di dominasi oleh metode pembelajaran secara konvesional dan tanpa menggunakan media. Hal ini memunculkan situasi belajar yang pasif bagi siswa. Siswa hanya duduk, mendengarkan, dan mencatat materi yang disampaikan oleh guru. Hal ini mengakibatkan pemahaman menjadi rendah. Bahkan siswa tidak mampu mendefinisikan kembali isi materi yang telah dipelajari dengan bahasanya sendiri. Hal tersebut juga memunculkan paradigma bahwa matematika merupakan pelajaran yang sulit dipahami dan membosankan.

Berdasarkan hasil pengamatan yang telah dilakukan di kelas II SDN Simpeureum I, permasalahan pembelajaran matematika siswa ini terlihat dari pemahaman konsep matematis siswa. Pertama, menyatakan ulang konsep yang telah dipelajari dengan contoh soal sebagai berikut. $5 \times 4=4+4+4+4+$ $4=20$. Kebanyakan siswa dalam proses pengerjaannya belum sesuai dikarenakan siswa tidak mengungkapkan ulang kembali konsep pengejaannya langsung pada hasil. Kedua, Mengklasifikasikan objek-objek berdasarkan konsep matematika. Pada mengklasifikasikan, sifat pertukaran belum bisa dipahami oleh siswa. Contoh soalnya: 3 x $6=6+6+6=18$ dan $6 \times 3=3+3+3+3$ $+3+3=18$. Ketiga, Menyajikan konsep dalam berbagai representasi. Contoh soalnya : $5 \times 3=3+3+3+3+3=15$. Pada tahap ini siswa belum mampu menjelaskan kembali menggunakan media yang telah tersedia. Masalah ini menunjukkan perlu adanya perbaikan pemahaman konsep matematis siswa.

Pemahaman konsep matematis sangat penting karena ketika siswa paham akan suatu konsep, maka siswa akan mampu mengingat pelajaran matematika yang telah dipelajarinya dalam jangka waktu yang panjang. Melalui pemahaman konsep matematis siswa yang baik, maka akan memunculkan pola pikir siswa yang kritis. Siswa juga diharapkan dapat mengemukakan kembali hasil kerjanya baik secara lisan ataupun dalam bentuk tulisan kepada orang lain atau teman sebayanya supaya siswa maupun teman sebayanya bisa benar-benar memahaminya.
Alternatif tindakan untuk mengatasi permasalahan tersebut, salah satunya melalui penggunaan media dalam proses pembelajaran. Media kantong bergambar menjadi media yang dapat digunakan untuk siswa memahami konsep matematis mengenai materi perkalian bilangan yang hasilnya dua angka. Menurut Arsyad (2015: 89) menyatakan bahwa "Media gambar dapat memperlancar pemahaman, memperkuat ingatan, menumbuhkan minat siswa, dan dapat memberikan hubungan antara isi materi pelajaran dengan dunia nyata." Penggunaan media akan menimbulkan suasana belajar yang aktif dan menyenangkan. Selain itu, adanya media ini akan merubah pandangan siswa terhadap pada mata pelajaran matematika menjadi mata pelajaran yang menyenangkan. Semua siswa dilibatkan secara langsung menggunakan media kantong bergambar sehingga media ini akan meningkatkan pemahaman konsep matematis siswa. Dengan demikian, penggunaan media kantong bergambar diharapkan dapat meningkatkan pemahaman konsep matematis siswa pada materi perkalian bilangan yang hasilnya dua angka.

\section{Pemahaman Konsep Matematis}

Guru dalam pembelajaran Matematika dituntut untuk lebih inovatif. Pemahaman siswa terhadap materi menjadi pertimbangan guru dalam melakukan inovasi pembelajaran. Menurut Jihad dan Abdul (2012: 16) menyatakan bahwa pemahaman meliputi Penerimaan dalam komunikasi secara akurat, menempatkan hasil komunikasi dalam bentuk penyajian yang berbeda, mengorganisasikannya secara setingkat tanpa merubah pengertian dan dapat mengeksplorasikannya. Sejalan dengan pendapat di atas, Bloom (Susanto, 2014: 6) mengartikan pemahaman sebagai kemampuan untuk menyerap arti dari materi atau bahan yang dipelajari. Lebih lanjut Bloom (Siregar, 2013: 2) mengatakan bahwa pemahaman mencakup tujuan, tingkah laku, atau tanggapan mencerminkan sesuatu pemahaman pesan tertulis yang termuat dalam satu komunikasi. Oleh sebab itu siswa dituntut untuk memahami atau mengerti apa yang sedang dikomunikasikan dan dapat memanfaatkan isinya dengan 
menghubungkannya dengan hal-hal yang lain. Dengan demikian pemahaman merupakan kemampuan siswa untuk mengerti atau memahami sesuatu setelah sesuatu itu diketahui dan diingat untuk kemudian mampu memberikan gambaran, contoh dan penjelasan yang lebih luas dan memadai atas apa yang telah diketahuinya dan dapat mengomunikasikan kepada orang lain.

Matematika terdiri dari berbagai konsep yang tersusun secara hierarkis, sehingga pemahaman terhadap konsep-konsep matematika merupakan bagian yang sangat penting dalam proses pembelajaran. Sebagaimana yang dikemukakan oleh Skeel (Dahar, 2006: 62) mengemukakan bahwa konsep merupakan suatu abstraksi mental yang mewakili satu kelas stimulus. maksudnya, konsep itu merupakan suatu pengabstarakan dari sejumlah benda yang memiliki karakteristik yang sama, untuk kemudian diklasifikasikan atau dikelompokkan. Pendapat lain dari Bahri (2008: 30) mengatakan konsep adalah satuan arti yang memiliki sejumlah objek yang mempunyai ciri yang sama. Lebih sederhana Susanto (2014: 8) mengatakan bahwa konsep merupakan sesuatu yang tergambar dalam pikiran, suatu pemikiran, gagasan, atau suatu pengertian. Lebih lanjut, Susanto (2016: 8) mengemukakan bahwa orang yang telah memiliki konsep, berarti orang tersebut telah memiliki pemahaman yang jelas tentang suatu konsep atau citra mental tentang sesuatu. Berdasarkan beberapa pemaparan di atas, dapat dikatakan bahwa konsep merupakan bagian dari materi pembelajaran yang memiliki makna penting untuk dipelajari bagi perkembangan intelektual siswa.

Pemahaman konsep merupakan hal yang sangat penting, karena dengan penguasaan konsep akan memudahkan siswa dalam mempelajari suatu materi pelajaran. Suherman (Sanjaya, 2009: 70) mengemukakan bahwa pemahaman konsep adalah kemampuan peserta didik yang berupa penguasaan sejumlah materi pelajaran, tetapi mampu menggunakan kembali dalam bentuk lain yang mudah dimengerti, memberikan interprestasi data dan mampu mengaplikasikan konsep yang sesuai dengan struktur kognitif yang dimilikinya. Pada saat belajar matematika siswa akan menemukan berbagai rumus yang perlu dihafalkan, sehingga pemahaman konsep siswa harus baik. Hamalik (Risnawati, 2008: 63) mengatakan pemahaman konsep matematika adalah menguasai sesuatu berupa kelas atau kategori stimuulasi dalam matematika yang memiliki ciri-ciri umum. Lebih lanjut, Suherman, dkk (Indra, 2015: 199) mengatakan bahwa pemahaman konsep adalah konsepkonsep matematika tersusun secara hirerarkis, terstruktur, logis dan sistematis mulai dari konsep yang paling sederhana sampai pada konsep yang paling kompleks. Pemahaman konsep merupakan suatu kemampuan yang dimiliki oleh individu sehingga dapat memberikan suatu pemahaman terhadap suatu kajian. Dengan demikian dapat diambil kesimpulan bahwa pemahaman konsep matematis adalah suatu kemampuan kognitif siswa dalam memahami materi-materi matematis yang terangkum dalam mengemukakan gagasan, mengolah informasi, dan menjelaskan dengan kata-kata sendiri melalui proses pembelajaran guna memecahkan masalah sesuai dengan aturan yang didasarkan pada konsep. Siswa yang memiliki pemahaman tentang suatu konsep adalah siswa yang dapat mengembangkan pengetahuannya, dapat menafsirkan, mencontohkan, mengklasifikasikan, merangkum, menyimpulkan, membandingkan, menjelaskan suatu obyek atau peristiwa dengan bahasanya sendiri. Oleh karena itu, pemahaman konsep matematis sangat penting, karena dengan penguasaan konsep matematis akan mempermudah siswa dalam mempelajari matematika dan menerapkannya dalam kehidupan sehari-hari.

\section{Indikator Pemahaman Konsep Matematis}

Pemahaman konsep matematis memiliki indikator yang dapat dijadikan pijakan oleh guru dalam mengembangkan materi pembelajaran. Menurut Lestari dan Yudhanegara (2015: 81) mengatakan bahwa kemampuan pemahaman matematis adalah kemampuan menyerap dan memahami ide-ide matematika". Indikator kemampuan pemahaman matematis yaitu:
1) Mengidentifikasi dan membuat contoh dan bukan contoh. 
2) Menerjemahkan dan menafsirkan makna simbol, tabel, diagram, gambar, grafik, serta kalimat matematis.

3) Memahami dan menerapkan ide matematis.

4) Membuat suatu ekstrapolasi (perkiraan). Sedangkan Menurut Kilpatrik et al (Lestari dan Yudhanegara, 2015: 81) mengatakan bahwa pemahaman konsep merupakan kemampuan yang berkenaan dengan memahami ide-ide matematika yang menyeluruh dan fungsional. Indikator dari pemahaman konsep matematis diantaranya:

1) Menyatakan ulang konsep yang telah dipelajari;

2) Mengklasifikasikan objek-objek berdasarkan konsep matematika;

3) Menerapkan konsep secara algoritma;

4) Memberikan contoh atau kontra contoh di konsep yang dipelajari;

5) Menyajikan konsep dalam berbagai representasi; dan

6) Mengaitkan berbagai konsep matematika secara internal atau eksternal.

Berdasarkan indikator-indikator tersebut peneliti menggunakan tiga indikator yang dikemukakan oleh Kilpatrik yang pertama, menyatakan ulang konsep yang telah dipelajari; kedua, mengklasifikasikan objekobjek berdasarkan konsep matematika; ketiga, menyajikan konsep dalam berbagai representasi. Peneliti menggunakan tiga indikator tersebut karena siswa kelas II SD termasuk pada tahap operasional konkret yang berada pada usia 7-11 tahun, anak baru mampu berpikir sistematis mengenai bendabenda dan peristiwa-peristiwa yang konkret. Adapun tahap perkembangan kognitif menurut Piaget (Nurisan dan Agustin, 2013: 16) yaitu (1)Tahap Sensorik-Motor (0-2 tahun) yakni hanya membangun suatu pemahaman tentang dunia melalui pengkoordinasian pengalamanpengalaman sensor dengan tindakan fisik. (2) Tahap Pra Operasional (2-7 tahun) yakni anak mulai mempresentasikan dunia dengan katakata dan gambar-gambar. (3) Tahap Operasional Konkret (7-11 tahun) yakni anak dapat bepikir secara logis mengenai peristiwa yang konkret dan mengklasifikasikan benda kedalam bentuk yang berbeda. (4) Tahap Formal Operasional (11-dewasa) yakni anak remaja berfikir dengan cara yang lebih abstrak dan logis pemikiran lebih idealis.
Peneliti melihat bahwa ketiga indikator tersebut tepat digunakan untuk mengukur pemahaman konsep matematis pada materi perkalian bilangan yang hasilnya dua angka dalam pelajaran matematika. Siswa dikatakan memahami konsep apabila siswa mampu 1). Menyatakan ulang sebuah konsep; 2). Mengklasifikasikan objek-objek berdasarkan konsep matematika; 3) Menyajikan konsep dalam berbagai bentuk representasi matematis.

\section{Media Pembelajaran Kantong Bergambar}

Berdasarkan rancangannya, media pembelajaran dibuat mulai dari yang sederhana sampai dengan perencanaan yang sangat kompleks. Sadiman dkk (2008: 83) mengelompokkan media pembelajaran kedalam dua jenis, yaitu "media by utilization dan media by design". Adapun penjelasan dari kedua media pembelajaran tersebut adalah:

1) Media by utilization

Media yang sudah tersedia dilingkungan sekolah atau tersedia di pasaran, dalam hal ini media dirancang secara khusus oleh perusahaan tertentu sesuai dengan kurikulum yang berlaku diproduksi secara massal dan biasanya harganya relatif murah sehingga guru dengan mudah dapat memiliki dan menggunakannya karena media ini sudah siap pakai.

2) Media by design

Media yang menuntut guru atau ahli media untuk merancang media sesuai dengan kebutuhan dan tujuan pembelajaran tertentu.

Sejalan dengan pendapat di atas, Ari (2014: 48) mengatakan bahwa media pembelajaran terbagi ke dalam 2 jenis yang diantaranya:

1) Media yang dirancang (by design), yaitu media dan sumber belajar yang secara khusus dirancang atau dikembangkan oleh pendidik sebagai komponen pada sistem pembelajaran untuk memberikan fasilitas belajar yang terarah kepada peserta didik dan bersifat formal.

2) Media yang dimanfaatkan (by utilization), yaitu media dan sumber belajar yang tidak didesain khusus oleh pendidik untuk keperluan pembelajalan dan keberadaannya dapat ditemukan, diterapkan dan dimanfaatkan untuk keperluan pembelajaran. 
Dengan demikian, media pembelajaran harus dipersiapkan dengan baik untuk meningkatkan proses pembelajaran. Kedua media pembelajaran tersebut dapat membantu guru untuk menyampaikan suatu isi dari materi dan gurupun dapat memilih media pembelajaran yang akan digunakan dengan menyesuaikan terlebih dahulu antara materi dan media pembelajaran. Pada saat akan memulai suatu pembelajaran, guru dapat menggunakan media pembelajaran yang sudah jadi maupun kita merancang media pembelajaran terlebih dahulu sesuai dengan materi dan tujuan pembelajaran yang diharapkan. Berdasarkan pemaparan tersebut maka media kantong bergambar merupakan media by design. Media kantong bergambar dibuat sendiri oleh guru yang digunakan untuk keperluan pembelajaran sesuai dengan materi dan tujuan pembelajaran yang hendak dicapai.

Media ini dibuat untuk meningkatkan pemahaman konsep matematis siswa. Adapun tata cara pembuatan dari media kantong bergambar adalah sebagai berikut:

1. Sediakan satu buah triplek.

2. Potong triplek menjadi bentuk persegi panjang dengan ukuran lebar $70 \mathrm{~cm}$ dan panjang $40 \mathrm{~cm}$.

3. Lukislah triplek secara abstrak dengan contoh membuat garis-garis tak beraturan.

4. Gunakan cat untuk mewarnai triplek yang telah digambar.

5. Tunggu sampai cat benar-benar kering kurang lebih selama satu hari.

6. Gunakan solatif hitam kemudian tempelkan pada bagian sisi-sisi triplek.

7. Pasangkan vel crow (perepet) pada dua bagian triplek dengan menggunakan paku.

8. Sediakan sebanyak mungkin gelas minuman plastik yang bergambaar.

9. Potong bagian atas pada gelas minuman plastik, kemudian tempelkan vel crow (Perepet) yang berukuran.

Media kantong bergambar merupakan media yang mudah dibuat dan digunakan oleh guru. Menurut Sadiman, (Wibawa dan Mukhti, 2001: 42) mengemukakan kelebihan media gambar yang diantaranya murah harganya; mudah didapat; mudah digunakan; dapat memperjelas suatu masalah; lebih realistis; membantu mengatasi keterbatasan pengamatan; dan mengatasi keterbatasan ruang. Lebih lanjut Indriana (2011: 64-65) mengemukakan bahwa media gambar mempunyai keunggulan yang diantaranya sudah umum digunakan, mudah dimengerti, dapat dinikmati, mudah dan murah didapat atau dibuat, dan banyak memberikan penjelasan dari pada menggunakan media verbal. Sejalan dengan pendapat di atas, Daryanto (2011: 100) mengatakan bawa kelebihan-kelebihan dari media gambar diantaranya: (1) Mudah dimanfaatkan di dalam kegiatan belajar mengajar karena praktis tanpa memerlukan perlengkapan apaapa. (2) Harganya relatif murah dari pada jenis-jenis media pengajaran lainnya. (3) gambar dapat dipergunakan dalam banyak hal, untuk berbagai jenjang pengajaran dan berbagai disiplin ilmu. (3) Gambar dapat menerjemahkan konsep atau gagasan yang abstrak menjadi lebih realistik.

Dengan demikian, media gambar atau foto mampu memberikan secara detail dalam bentuk gambar yang apa adanya, sehingga siswa mampu untuk mengingatnya dengan lebih baik. Selain itu, media gambar juga bisa memecahkan masalah yang ada dalam media verbal yaitu, dalam hal keterbatasan daya ingat dalam bercerita atau menjelaskan sesuatu. Media gambar ini menjelaskan bahwa dengan penggunaan media dalam setiap proses pembelajaran maka pembelajaran akan lebih bermakna.

\section{Metode dan Desain Penelitian}

Bentuk penelitian yang dilaksanakan dengan menggunakan penelitian tindakan kelas (classroom action research). Sanjaya (2013: 149) mengatakan PTK adalah proses pengkajian masalah pembelajaran di dalam kelas melalui refleksi diri dan upaya untuk memecahkannya dengan cara melakukan berbagai tindakan yang terencana dalam situasi nyata serta menganalisis setiap pengaruh dari tindakan tersebut. Dengan demikian, penelitian tindakan kelas merupakan penelitian yang berangkat dari topik permasalahan dalam kelas dan upaya yang dilakukan oleh guru untuk memperbaikinya agar sesuai dengan tujuan yang hendak dicapai.

Pelaksanaan penelitian tindakan kelas dengan menggunakan desain model John Elliot (Wiriaatmadja, 2010: 64) yang dalam satu 
siklus terdiri dari beberapa tindakan berikut tahapan-tahapannya meliputi identifikasi masalah, dilanjutkan dengan memeriksa di lapangan, kemudian melakukan perencanaan siklus I, pelaksanaan tindakan siklus I diikuti dengan observasi, kemudian melakukan reconnaisance/diskusi kegagalan dan pengaruhnya/refleksi, selanjutnya melakukan perbaikan untuk dilaksanakan pada siklus berikutnya sampai tujuan penelitian tercapai.

\section{Subyek Penelitian}

Penelitian tindakan kelas ini dilaksanakan di Sekolah Dasar Negeri Simpeureum I Kecamatan Cigasong Kabupaten Majalengka. Subjek penelitian adalah siswa kelas dua sebanyak 30 orang, terdiri dari 14 orang siswa laki-laki dan 16 orang siswa perempuan Fokus dalam penelitian tindakan kelas ini adalah pemahaman konsep matematis materi perkalian bilangan yang hasilnya dua angka pada mata pelajaran matematika di kelas II Sekolah Dasar.

\section{Instrumen Penelitian}

1. Butir Soal Evaluasi

Butir soal dibuat untuk mengukur pemahaman konsep matematis siswa terhadap materi yang telah dipelajari yang disesuaikan dengan indikator pemahaman matematis yang telah ditetapkan yaitu menyatakan ulang konsep yang telah dipelajari, mengklasifikasikan objekobjek berdasarkan konsep matematika dan menyajikan konsep dalam berbagai representasi. . Tes ini digunakan untuk mengetahui peningkatan pemahaman konsep matematis siswa setelah menerapkan media kantong bergambar.

2. Lembar Observasi

Lembar observasi dalam penelitian ini yaitu menggunakan dua lembar observasi yaitu lembar observasi siswa dan lembar observasi aktivitas guru. Lembar observasi aktivitas siswa digunakan untuk mengetahui kegiatan siswa dalam kegiatan belajar mengajar dengan menggunakan media kantong bergambar. Sedangkan lembar observasi aktivitas guru dalam pembelajaran dengan menggunakan media kantong bergambar.

3. Lembar Wawancara
Lembar wawancara yang digunakan dalam penelitian ini adalah lembar wawancara untuk siswa. Lembar wawancara ini disusun dengan tujuan untuk mengetahui aktivitas maupun respon siswa ketika mengikuti kegiatan pembelajaran dengan menggunakan media kantong bergambar.

4. Lembar Catatan Lapangan

Lembar catatan lapangan digunakan untuk mencatat aktivitas siswa dalam kegiatan pembelajaran dengan menggunakan media kantong bergambar. Catatan lapangan dibuat sebagai data penunjang dari hasil observasi aktivitas siswa.

\section{Analisis Data}

Data dari hasil penelitian ini berupa data kualitatif dan data kuantitatif. Data kualitatif diperoleh melalui hasil observasi, hasil wawancara, catatan lapangan. Analisis data kualitatif menggunakan analisis data Miles dan Huberman. Menurut Miles and Huberman (Sugiyono, 2015: 337) mengatakan bahwa aktivitas dalam analisis data kualitatif dilakukan secara interaktif dan berlangsung secara terus menerus sampai tuntas, sehingga datanya sudah jenuh. Adapun langkah-langkah analisis data kualitatif Miles dan Huberman yaitu reduksi data, penyajian data, penarikan kesimpulan dan verifikasi data. Hasil analisis data kemudian dideskripsikan dalam bentuk narasi. Adapun data kuantitatif diperoleh dari butir soal evaluasi pemahaman konsep matematis. Langkah-langkah dalam melakukan analisis data kuantitatif adalah sebagai berikut: (1) mengetahui nilai rata-rata kelas dengan menggunakan rumus

$$
\overline{\mathrm{X}}=\frac{2 \mathrm{X} \mid}{\mathrm{N}}
$$

(Sudjana, 2016: 10)

keterangan :

$\begin{array}{ll}\mathrm{X} & =\text { Mean atau nilai rata-rata } \\ \sum \mathrm{X} & =\text { Jumlah skor keseluruhan } \\ \mathrm{N} & =\text { Banyaknya sampel }\end{array}$

(2) menghitung persentase ketuntasan belajar. Indikator keberhasilan penelitian ini adalah Kriteria Ketuntasan Minimal (KKM) yang telah ditetapkan untuk kelas II SDN Simpeureum I Kelurahan Simpeureum Kecamatan Cigasong Kabupaten Majalengka 
yaitu 273 . Siswa dikatakan berhasil jika siswa mampu mencapai ketuntasan belajar sesuai dengan nilai KKM. Persentase ketuntasan belajar siswa secara klasikal menggunakan rumus sebagai berikut:

$$
\rho=\frac{\sum \text { siswa yang tuntas belajar }}{\text { Ejumlah siswa }} \times 100 \%
$$

keterangan:

$\rho=$ Persentase Ketuntasan Belajar

$100 \%=$ Bilangan Tetap

Sucahyo (2012: 3)

Pada penelitian ini ketuntasan belajar siswa dapat dilihat dari segi proses dan hasil. Dari segi proses, pembelajaran dikatan berhasil dan berkualitas apabila $80 \%$ atau 20 orang siswa dari 30 siswa terlihat aktif dalam proses pembelajaran. Sedangkan dari segi hasil pembelajarannya dikatakan berhasil apabila kriteria ketuntasan individu dapat dicapai 273 . Jika siswa mendapat $\leq 73$ maka siswa tersebut belum tuntas. Jika siswa kelas II telah mencapai KKM sebanyak $80 \%$ maka penelitian dianggap berhasil. Seperti yang dikemukakan oleh Mulyasa (2013: 87) sebagai berikut dari segi proses pembelajaran dikatakan berhasil dan berkualitas apabila seluruhnya atau setidak-tidaknya sebagian besar $(80 \%)$ peserta didik terlihat secara aktif, baik fisik, mental, maupun sosial dalam proses pembelajaran, disamping menunjukan kegairahan belajar yang tinggi, semangat belajar yang besar, dan rasa percaya pada diri sendiri. Sedangkan dari segi hasil, proses pembelajaran dikatakan berhasil apabila terjadi perubahan perilaku yang positif pada diri peserta didik seluruhnya atau setidaktidaknya sebagian besar (80).

\section{Hasil Penelitian dan Pembahasan Siklus I}

Tahap perencanaan ini mencakup menyusun Rencana Pelaksanaan Pembelajaran (RPP), menyiapkan sumber dan media pembelajaran, menyiapkan lembar kerja siswa, menyiapkan lembar observasi yang akan digunakan dalam penelitian dan menyiapkan tes akhir Siklus pertama (evaluasi) di setiap tindakan.

Pada tindakan satu materi yang diajarkan yaitu tentang perkalian bilangan, kompetensi dasar yang di ambil adalah melakukan perkalian bilangan yang hasilnya dua angka. $\begin{array}{lrr}\text { Sedangkan } & \text { indikatornya } & \text { mencakup } \\ \text { menjelaskan } & \text { pengertian } & \text { perkalian, }\end{array}$ menyebutkan simbol perkalian, menghitung perkalian bilangan yang hasilnya dua angka. Teknik yang digunakan dalam tindakan satu yaitu ceramah, tanya jawab, penugasan dan diskusi. Adapun media yang digunakan dalam menunjang proses pembelajaran yaitu media kantong bergambar, gambar buah-buahan, lembar kerja siswa dan lembar evaluasi.

Pada tindakan dua materi yang diajarkan yaitu perkalian bilangan, kompetensi dasar yang di ambil adalah melakukan perkalian bilangan yang hasilnya dua angka. Sedangkan indikatornya menghapal perkalian dengan bernyanyi dan menggunakan jari, menghitung perkalian bilangan yang hasilnya dua angka, dan menyelesaikan perkalian dengan menggunakan tabel. Teknik yang digunakan dalam tindakan dua yaitu ceramah, tanya jawab dan latihan. Adapun media yang digunakan dalam menunjang proses pembelajaran yaitu media kantong bergambar, gambar binatang, lembar kerja siswa dan lembar evaluasi.

Pada tahap pelaksanaan terdapat beberapa temuan esensial. Temuan kesatu pada kegiatan awal pembelajaran guru masih belum bisa mengondisikan kelas, hal ini terlihat pada awal pembelajaran suasana kelas yang masih ramai, karena pada tindakan satu masih banyak siswa yang berbicara dengan teman sebangkunya dan masih banyak siswa yang belum bisa duduk secara rapih. Selain itu siswa masih belum bersemangat dalam belajar yang terlihat dari keaktifan siswa menjawab pertanyaan dari guru ketika guru melaksanakan apersepsi. Pada saat apersepsi dilakukan hanya sebagian siswa yang merespon atau menjawab pertanyaan dari guru.

Temuan kedua pada kegiatan inti. Pada tahap eksplorasi terlihat kurang berjalan secara optimal hal ini terlihat dari ketika guru sedang menjelaskan materi dan memberikan contoh dari materi yang diajarkan menggunakan media kantong bergambar, hanya sebagian siswa yang memperhatikan dan siswa lainnya sibuk bermain-main dengan temannya. Hal ini dikarenakan kejailan teman sebangkunya. Selanjutnya pada tahap elaborasi, ketika guru membagi kelompok ada beberapa siswa yang ingin bertukar dengan 
kelompok lain. Hali ini dikarenakan persepsi negatif siswa terhadap teman lainnya yang berpikir kalau teman lain yang sekelompok dengan nya mempunyai kognitif yang kurang. Setelah dia mencari anggota lain yang ingin bertukar kelompok dengan dirinya akhirnya siswa tersebut bertukar kelompok. Pada saat siswa berada dikelompoknya masing-masing, kerja kelompok belum berjalan secara optimal. Hal ini diakibatkan karena sebagian siswa yang masih bermain-main dengan temannya dan mereka saling mengandalkan satu sama lain sehingga mengakibatkan kegiatan kerja kelompok tidak berjalan sesuai yang diharapkan. Faktor lain yang terjadi pada tahap eksplorasi adalah siswa kurang percaya diri ketika guru meminta dia maju untuk menyelesaikan soal dengan menggunakan media kantong bergambar, mereka merasa takut tidak bisa menyelesaikannya dengan benar. Terakhir pada tahap konfirmasi, guru melakukan proses tanya jawab sebagai penguatan di akhir pelajaran. Pada proses tanya jawab tidak berjalan dengan baik dikarenakan siswa hanya mencatat dan mengobrol dengan teman sebangkunya. Akan tetapi dengan dibantu oleh guru kelas, kesulitan tersebut dapat terselesaikan.

Temuan ketiga yaitu pada kegiatan penutup, belum adanya rasa percaya diri siswa untuk bertanya mengenai materi yang telah dipelajari kepada guru setelah pelajaran berakhir. Hanya sebagian siswa yang rasa percaya dirinya sudah tumbuh dengan bertanya mengenai materi yang telah dipelajari sebagai rasa ingin tahu nya yang tinggi.

Pemahaman konsep matematis siswa pada siklus pertama tindakan satu dan dua dilihat pada tabel 1 di bawah ini:

Tabel 1.

Rekapitulasi pemahaman matematis siswa Siklus I

\begin{tabular}{|c|c|c|}
\hline $\begin{array}{c}\text { Nilai Rata- } \\
\text { rata }\end{array}$ & $\begin{array}{c}\text { Jumlah siswa } \\
\text { Tuntas }\end{array}$ & $\begin{array}{c}\text { Persentase } \\
\text { Ketuntasan }\end{array}$ \\
\hline 61,67 & 12 & $40 \%$ \\
\hline
\end{tabular}

Berdasarkan tabel di atas terlihat pemahaman konsep matematis yang menunjukkan bahwa nilai rata-rata siswa yaitu 61,67. Hasil ini membuktikan bahwa sebagian besar siswa belum berhasil mencapai KKM. Nilai rata-rata kelas belum mampu mencapai KKM yaitu 73. Selain itu apabila kita melihat pada kriteria ketuntasan belajar secara klasikal pembelajaran pada siklus pertama dapat dikatakan belum tuntas. Hal tersebut dikarenakan dari 30 siswa, hanya 12 siswa yang berhasil mendapat nilai $\geq \mathrm{KKM}$ dengan persentase ketuntasan belajar secara klasikal yaitu sebesar $40 \%$. Jadi dapat dikatakan bahwa siklus pertama belum memenuhi syarat ketuntasan belajar klasikal yaitu sebesar $75 \%$.

Tahap refleksi merupakan suatu kegiatan untuk menentukan perbaikan-perbaikan proses pembelajaran pada siklus pertama. Adapun hal-hal yang perlu diperhatikan untuk siklus selanjutnya adalah sebagai berikut: (1) Pada kegiatan awal, pada pembelajaran selanjutnya guru harus melakukan apersepsi yang lebih menarik lagi dengan cara melakukan tanya jawab secara acak untuk memberikan semangat kepada siswa agar siswa dapat termotivasi untuk belajar. Hal ini sesuai dengan pendapat yang dikemukakan oleh Sumantri (2005: 379) bahwa motivasi belajar adalah daya penggerak yang ada dalam diri seseorang baik bersifat intrinsik maupun ekstrinsik yang dapat menimbulkan kegiatan belajar, memberi arah, dan menjamin kelangsungan belajar serta berperan dalam penumbuhan beberapa sifat positif, seperti kegairahan, rasa senang belajar sehingga menambah pengetahuan dan dan keterampilan.

(2) Pada kegiatan inti, pada pembelajaran selanjutnya guru harus mampu mengondisikan dan mengelola kelas secara baik dengan cara menukar tempat duduk setiap pertemuannya dan guru harus menunjuk siswa secara acak untuk menjawab pertanyaan-pertanyaan yang dilontarkan oleh guru supaya siswa bisa teralihkan perhatiaannya dan menumbuhkan rasa percaya diri siswa sehingga siswa dapat terlibat aktif dalam pembelajaran. Hal ini sesuai dengan pendapat Poerwadarminto (2001: 24) yang mengatakan bahwa keaktifan belajar siswa adalah suatu keadaan dimana siswa aktif dalam belajar. keaktifan belajar siswa dapat dilihat dari keterlibatan siswa dalam proses belajar mengajar yang beraneka ragam seperti saat mendengarkan penjelasan guru, diskusi, membuat laporan pelaksanaan tugas dan lain sebagainya. (3) Pada kegiatan 
akhir, guru menyimpulkan pembelajaran bersama kemudian guru yang terlebih dahulu melakukan tanya jawab ke siswa untuk merespon siswa agar melatih mengeluarkan ide atau pendapatnya dan menumbuhkan rasa percaya dirinya dengan diberikan penghargaan atas jawaban yang telah dikemukakan tanpa adanya proses menyalahkan atas jawabannya akan tetapi dengan cara meluruskan jawaban siswa.

\section{Siklus II}

Tahap perencanaan ini mencakup menyusun Rencana Pelaksanaan Pembelajaran (RPP), menyiapkan sumber dan media pembelajaran, menyiapkan lembar kerja siswa, menyiapkan lembar observasi yang akan digunakan dalam penelitian dan menyiapkan tes akhir Siklus kedua (evaluasi) di setiap tindakan.

Pada tindakan satu materi yang diajarkan yaitu tentang operasi hitung bilangan, kompetensi dasar yang di ambil adalah melakukan perkalian bilangan yang hasilnya dua angka. Sedangkan indikatornya mencakup menuliskan rumus sifat-sifat perkalian, mengidentifikasi sifat-sifat perkalian, dan mencontohkan sifat-sifat perkalian. Teknik yang digunakan dalam tindakan satu yaitu ceramah, tanya jawab, penugasan dan diskusi. Adapun media yang digunakan dalam menunjang proses pembelajaran yaitu media kantong bergambar, gambar sayur-sayuran, lembar kerja siswa dan lembar evaluasi.

Pada tindakan dua materi yang diajarkan yaitu operasi hitung bilangan, kompetensi dasar yang di ambil adalah melakukan perkalian bilangan yang hasilnya dua angka. Sedangkan indikatornya mencakup menuliskan hasil perkalian dengan membilang loncat, menghitung perkalian dengan membilang loncat dan mendatar, menampilkan hasil perkalian yang telah dikerjakan. Teknik yang digunakan dalam tindakan dua yaitu ceramah, latihan, penugasan, diskusi. Adapun media yang digunakan dalam menunjang proses pembelajaran yaitu media kantong bergambar, gambar makanan, lembar kerja siswa dan lembar evaluasi.

Pada tahap pelaksanaan terdapat beberapa temuan esensial. Temuan kesatu pada kegiatan awal pembelajaran sudah terlihat kalau siswa mulai bersemangat dalam belajar terlihat dari keaktifan siswa menjawab pertanyaan dari guru ketika melaksanakan apersepsi. Apersepsi yang menantang bagi siswa telah dipraktikan oleh guru sehingga siswa termotivasi untuk mengikuti pembelajaran dan hanya sebagian siswa yang tidak merespon atau menjawab pertanyaan dari guru.

Temuan kedua pada kegiatan inti. Pada tahap eksplorasi guru berhasil menarik perhatian siswa untuk dapat belajar secara aktif dan kondusif. Hal ini disebabkan oleh adanya media kantong bergambar. Sebelum pembelajaran matematika dimulai guru menunjukkan media kantong bergambar beserta gambar sayur-sayuran dan makanan kepada seluruh siswa, sehingga siswa antusias untuk mengkuti pembelajaran. Kemudian, pada tahap elaborasi, siswa mulai terlibat aktif dalam proses pembelajaran karena guru selalu melibatkan seluruh siswa menggunakan media kantong bergambar. Hal ini bisa terlihat dari antusias siswa saat mengikuti pembelajaran dengan belajar sambil bermain menggunakan media kantong bergambar. Ketika guru meminta siswa secara bergiliran untuk melakukan percobaan menggunakan media kantong bergambar sebagai alat bantu menyelesaikan masalah perkalian yang hasilnya dua angka siswa merasa senang. Selain itu, pada saat siswa berada di kelompoknya masing-masing, siswa sudah mulai berinteraksi secara baik dengan teman sekelompoknya. Hal ini dapat dilihat dari keterlibatan siswa mengikuti diskusi. Ketika pembagian kelompok dilaksanakan, tidak ada lagi siswa yang ingin bertukar kelompoknya dengan kelompok lain. Hal ini disebabkan karena pembagian kelompok dari setiap pertemuan tidak berubah, sehingga siswa bisa lebih mengenal satu sama lain. Walaupun dalam pembagian kelompok sudah mengalami perubahan terdapat kendala yang kurang dilakukan secara optimal yaitu pada saat pemaparan hasil diskusi volume suara siswa kurang terdengar. Hal ini disebabkan karena suasana kelas yang cukup gaduh mengakibatkan volume suara siswa kurang terdengar secara baik. Pada tahap konfirmasi, sebagian siswa belum paham terhadap pelajaran yang telah dipelajari. Hal tersebut disebabkan oleh keramaian yang dibuat oleh siswa laki-laki yang banyak bermain dengan teman sebangkunya yang mengganggu siswa lainnya untuk memperhatikan guru secara 
konsentrasi. Guna menyelesaikan kesulitan yang terjadi di dalam kelas peneliti dibantu oleh guru kelas sehingga kesulitan tersebut dapat terselesaikan.

Temuan ketiga pada kegiatan akhir, pembelajaran mulai berjalan secara baik sesuai dengan harapan yang diinginkan guru setelah mengikuti pembelajaran. Hal ini terlihat dari kegiatan siswa melakukan proses tanya jawab diakhir pembelajaran. Siswa mulai percaya diri untu menanyakan sesuatu hal tentang pelajarang yang telah dia pelajari kepada guru sehingga pemahaman konsep matematis siswa mulai meningkat secara perlahan. Akan tetapi tidak menutup kemungkinan bahwa ada sebagian siswa yang masih belum paham tentang pelajaran yang telah dipelajari sehingga peningkatan pemahaman konsepnya pun kurang.

Pemahaman konsep matematis siswa pada siklus kedua tindakan satu dan dua dilihat pada tabel 2 di bawah ini:

Tabel 2.

Rekapitulasi pemahaman matematis siswa Siklus II

\begin{tabular}{|c|c|c|}
\hline $\begin{array}{c}\text { Nilai rata- } \\
\text { rata }\end{array}$ & $\begin{array}{c}\text { Jumlah } \\
\text { siswa } \\
\text { Tuntas }\end{array}$ & $\begin{array}{c}\text { Persentase } \\
\text { Ketuntasan }\end{array}$ \\
\hline 65,23 & 20 & $66,67 \%$ \\
\hline
\end{tabular}

Berdasarkan tabel di atas terlihat pemahaman konsep matematis yang menunjukkan bahwa nilai rata-rata siswa yaitu 65,23 . Hasil ini membuktikan bahwa sebagian besar siswa belum berhasil mencapai KKM. Nilai rata-rata kelas belum mampu mencapai KKM yaitu 73 . Selain itu apabila kita melihat pada kriteria ketuntasan belajar secara klasikal pembelajaran pada siklus kedua dapat dikatakan belum tuntas. Hal tersebut dikarenakan dari 30 siswa, hanya 20 siswa yang berhasil mendapat nilai $\geq$ KKM dengan persentase ketuntasan belajar secara klasikal yaitu sebesar $65,67 \%$. Jadi dapat dikatakan bahwa siklus pertama belum memenuhi syarat ketuntasan belajar klasikal yaitu sebesar $75 \%$.

Pada tahap refleksi, hal-hal yang perlu diperhatikan guru diantaranya: (1) pada pembelajaran selanjutnya guru harus tetap melaksanakan apersepsi yang bersifat menantang dengan cara melakukan proses tanya jawab secara acak lagi dan diselingi dengan permainan. (2) dalam setiap pembelajaran guru selalu mempersiapkan media dan gambarnya secara maksimal supaya siswa bisa termotivasi untuk belajar secara aktif. Guru harus lebih dapat mengkondisikan kelas secara lebih optimal dengan cara lebih banyak melibatkan siswa dalam setiap proses pembelajaran nya agar kondisi kelas tidak menjadi ramai dan volume suara siswa bisa terdengar secara jelas. Pengelolaan kelas yang dilakukan oleh guru dari awal pembelajaran sampai pada akhir pembelajaran menciptakan suasana belajar yang kondusif. Hal ini sesuai dengan pendapat Wiyani (2013: 59) menyatakan bahwa manajemen kelas adalah keterampilan guru sebagai seorang leader sekaligus manajer dalam menciptakan iklim kelas yang kondusif untuk meraih keberhasilan kegiatan belajar mengajar. Hal ini merupakan salah satu cara yang dilakukan oleh guru untuk mencapai suatu keberhasilan belajar mengajar. Selajutnya, guru harus lebih memperhatikan dalam membimbing siswa dengan cara lebih aktif memberikan pertanyaan supaya mengalihkan perhatian siswa.

\section{Siklus III}

Tahap perencanaan ini mencakup menyusun Rencana Pelaksanaan Pembelajaran (RPP), menyiapkan sumber dan media pembelajaran, menyiapkan lembar kerja siswa, menyiapkan lembar observasi yang akan digunakan dalam penelitian dan menyiapkan tes akhir Siklus ketiga (evaluasi) di setiap tindakan.

Pada tindakan satu materi yang diajarkan yaitu tentang menyelesaikan masalah perkalian, kompetensi dasar yang di ambil adalah melakukan perkalian bilangan yang hasilnya dua angka. Sedangkan indikatornya mencakup mengemukakan permasalahan yang terjadi dilingkungannya, menyelesaikan masalah sehari-hari yang berhubungan dengan perkalian yang hasilnya dua angka, dan menerapkan konsep penyelesaian masalah di dalam kehidupan sehari-hari. Teknik yang digunakan dalam tindakan satu yaitu tanya jawab, penugasan, latihan dan diskusi. Adapun media yang digunakan dalam menunjang proses pembelajaran yaitu media kantong bergambar, gambar boneka, lembar kerja siswa dan lembar evaluasi. 
Pada tindakan dua materi yang diajarkan yaitu menyelesaikan masalah perkalian, kompetensi dasar yang di ambil adalah mengaitkan soal cerita perkalian dengan benda-benda yang ada di lingkungan kelas, memecahkan permasalahan yang ada di soal cerita dan mencontohkan soal cerita menggunakan media kantong bergambar. Teknik yang digunakan dalam tindakan dua yaitu ceramah, tanya jawab, penugasan dan diskusi. Adapun media yang digunakan dalam menunjang proses pembelajaran yaitu media kantong bergambar, gambar benda, lembar kerja siswa dan lembar evaluasi.

Pada tahap pelaksanaan, selama berlangsungnya proses pembelajaran yang dilakukan di siklus ketiga keaktifan siswa sudah mengalami peningkatan dengan memperlihatkan perubahan perilaku siswa dalam mengikuti pembelajaran. Peningkatan ini menunjukkan adanya perubahan dalam proses pembelajaran walaupun hanya ada beberapa kendala yang dihadapi. Temuan yang diperoleh peneliti dijadikan sebagai bahan dalam melakukan analisis dan refleksi atas tindakan pada siklus ketiga.

Temuan kesatu pada awal pembelajaran guru sudah mampu membangun suasana kelas yang menyenangkan dan aktif, hal ini terlihat dari kesiapan siswa untuk mengikuti pelajaran dengan masuk kelas secara tertib dan duduk dengan rapih. Selain itu, siswa sudah mampu mengubah paradigmanya tentang pelajaran matematika yang menakutkan dan membosankan menjadi pelajaran yang menyenangkan. Hal lain yang membuat siswa semangat belajar matematika dikarenakan apersepsi guru yang menantang bagi siswa berhasil dilakukan. Setiap pertemuan guru selalu melakukan apersepsi dengan menggali pengetahuan awal siswa dulu kemudian dikaitkan dengan pelajaran yang akan diajarkan.

Temuan kedua pada kegiatan inti. Pada tahap eksplorasi guru berhasil menarik perhatian siswa untuk dapat belajar secara aktif dan kondusif. Hal ini disebabkan oleh adanya media kantong bergambar. Sebelum pembelajaran matematika dimulai guru menunjukkan media kantong bergambar beserta gambar boneka dan benda kepada seluruh siswa, sehingga siswa antusias untuk mengkuti pembelajaran. Kemudian pada tahap elaborasi, siswa terlibat secara aktif dalam proses belajar. Hal ini dapat terlihat dari antusias siswa yang ingin maju kedepan untuk menyelesaikan soal cerita dengan menggunakan media kantong bergambar. Untuk itu, guru selalu melibatkan seluruh siswa menggunakan media kantong bergambar secara bergiliran. Ketika guru meminta siswa secara bergiliran untuk melakukan percobaan menggunakan media kantong bergambar sebagai alat bantu menyelesaikan soal cerita yang hasilnya dua angka siswa merasa senang. Selain itu, pada saat siswa berada di kelompoknya masingmasing, siswa sudah mampu bekerjasama dengan baik. Hal ini dapat dilihat dari keberanian siswa untuk menyampaikan pendapatnya. Setiap kelompok tidak saling mengandalkan satu sama lain, akan tetapi setiap kelompoknya saling bertukar pikiran dan bekerja sama secara kompak untuk dapat menyelesaikan soal cerita yang diberikan guru. Selain itu, pada saat menyampaikan pendapat dari hasil diskusi suaranya sudah terdengar secara jelas dan penggunaan bahasanya pun sudah baik. Sehingga setiap siswa bisa mendengarnya dan membuat suasana kelas menjadi kondusif. Pada tahap konfirmasi, hanya ada sebagian siswa belum paham terhadap pelajaran yang telah dipelajari. Hal tersebut disebabkan oleh mulai tidak konsentrasinya siswa untuk belajar dikarenakan kejahilan siswa laki-laki yang banyak bermain dengan teman sebangkunya yang mengganggu siswa lainnya untuk memperhatikan guru.

Temuan ketiga pada kegiatan akhir, pembelajaran berjalan secara optimal dan baik sesuai dengan harapan yang diinginkan guru setelah mengikuti pembelajaran. Hal ini terlihat dari kegiatan siswa melakukan proses tanya jawab diakhir pembelajaran. Siswa sudah mempunyai rasa percaya diri yang baik untuk menanyakan sesuatu hal tentang pelajaran yang telah dia pelajari kepada guru sehingga pemahaman konsep matematis siswa mengalami peningkatann walaupun secara perlahan.

Pemahaman konsep matematis siswa pada siklus ketiga tindakan satu dan dua dilihat pada tabel 3 di bawah ini:

Tabel 3. Rekapitulasi pemahaman matematis siswa Siklus III 


\begin{tabular}{|c|c|c|}
\hline $\begin{array}{c}\text { Nilai rata- } \\
\text { rata }\end{array}$ & $\begin{array}{c}\text { Jumlah } \\
\text { siswa } \\
\text { Tuntas }\end{array}$ & $\begin{array}{c}\text { Persentase } \\
\text { Ketuntasan }\end{array}$ \\
\hline 78,43 & 24 & $80 \%$ \\
\hline
\end{tabular}

Berdasarkan tabel di atas terlihat pemahaman konsep matematis yang menunjukkan nilai rata-rata siswa yaitu 78,43. Hasil ini menunjukkan adanya perubahan dan pembelajaran yang sudah berhasil karena nilai rata-rata kelas sudah berhasil mencapai KKM yaitu 73. Selain itu, apabila melihat pada kriteria ketuntasan belajar secara klasikal atau mastery learning dikatakan sudah tuntas. Hal tersebut dikarenakan dari 30 siswa, sebanyak 24 siswa yang berhasil mendapat nilai $\geq$ KKM dengan persentase ketuntasan belajar secara klasikal sebesar $80 \%$.

Pada tahap refleksi, proses pembelajaran yang telah dilakukan oleh peneliti telah sesuai dengan langkah-langkah yang ada dalam RPP dan sesuai dengan langkah-langkah penggunaan media kantong bergambar. Penggunaan media kantong bergambar sudah dirasa sangat baik oleh peneliti. Respon siswa terhadap kegiatan pembelajaran baik hal ini terbukti ketika pelaksanaan pembelajaran siswa sangat antusias menggunakan media kantong bergambar. Berikut gambar grafik keberhasilan penelitian tindakan kelas:

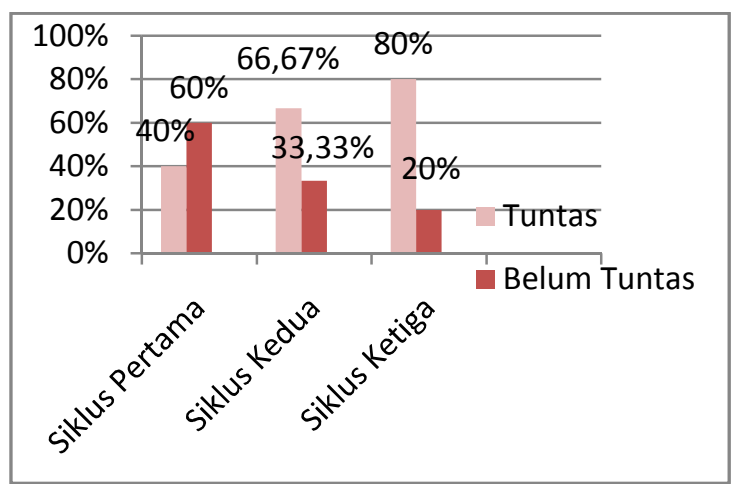

Gambar 1.

Grafik Peningkatan Ketuntasan Pemahaman Konsep Matematis

Merujuk kepada gambar di atas, maka dapat disimpulkan bahwa penelitian tindakan kelas ini tuntas pada Siklus III.

\section{Simpulan}

1. Proses pembelajaran matematika dengan menerapkankan media kantong bergambar secara keseluruhan berjalan dengan optimal. Hal ini terlihat dari keaktifan siswa dengan berpartisipasi mengikuti kegiatan pembelajaran dan menggunakan media kantong bergambar yang telah disediakan.

2. Penggunakan media kantong bergambar dalam pembelajaran matematika, mampu meningkatkan pemahaman konsep matematis pada tiap siklusnya.

\section{Daftar Pustaka}

Ari, D. (2014). Metode Pengembangan Sumber dan Media Pembelajaran. Malang: Genius Media.

Arsyad, A. (2015). Media Pembelajaran (eighteen ed). Jakarta: PT. Rajawali.

Bahri. (2008). Konsep dan Definisi Konseptual. Jakarta: PT. Raja Grafindo Persada.

Dahar, W. R. (2006). Teori-Teori Belajar dan Pembelajaran. Yogyakarta: Pustaka Belajar.

Daryanto. (2011). Media Pembelajaran. Bandung: Nurani Sejahtera.

Indra, M.R. dan Ishnaningrum, I. (2015). "Efektifitas Penggunaan Media Ict dalam Peningkatan Pemahaman Konsep Matematika." Mifa Learning Journals. Vol 2, (3). hlm.198-199.

Indriana, D. (2011). Ragam Alat Bantu Media Pengajaran. Yogyakarta: Diva Press.

Lestari dan Yudhanegara. (2015). Penelitian Pendidikan Matematika. Bandung: PT. Refika Aditama.

Mulyasa, E. (2013). Pengembangan dan implementasi kurikulum 2013. Bandung: PT Rosda Karya

Nurisan, J. A. dan Agustin, M. (2013). Dinamika Perkembangan anak \& Remaja Tinjauan Psikologi, Pendidikan dan Bimbingan (two ed). Bandung: PT. Refika Aditama. 
Susanto, A. (2014). Teori Belajar dan Pembelajaran di Sekolah Dasar. Jakarta: Kencana.

Poerwadarminto. (2001). Kamus Umum Bahasa Indonesia. Jakarta: Balai Pustaka.

Risnawati. (2000). Strategi Pembelajaran Matematika. Pekanbaru: Suska Press.

Sadiman, S. A. dkk. (2008). Media Pendidikan. Jakarta: PT. Raja Grafinndo Press.

Sanjaya, W. (2013). Penelitian Pendidikan Jenis, Metode dan Prosedur. Bandung: PRENAMEDIA GROUP.

. (2009). Strategi Pembelajaran Berorientasi Standar Proses Pendidikan. Jakarta: Kencana Pernada Media Group.

Siregar, S. (2013). "Meningkatkan Pemahaman dan Hasil Belajar Siswa Pada Mata Pelajaran Matematika dengan Menggunakan Software Graphmatica. Journal Penelitian, Vol 3, (1), hlm.1-9.

Sucahyo. (2012). Penggunaan Media Puzzle Untuk Meningkatkan Hasil Belajar Di Sekolah Dasar, PGSD FIP Universitas Negeri Surabaya. (Online), halaman 11. Tersedia: http://jurnalmahasiswa.unesa.ac.id/ind ek.phpl (03 Agustus 2018)

Sudjana, N. (2016). Penilaian Hail Proses Belajar Mengajar. Bandung: Rosdakarya.

Sugiyono. (2015). Metode Penelitian Pendidikan (Pendekatan Kuantitatif, Kualitatif, dan R\&D) (twenty ed). Bandung: Alfabeta.

Sumantri. (2005). Pengembangan Keterampilan Motorik Anak Usia Dini. Jakarta: Dinas Pendidikan.
Susanto, A. (2016). Teori Belajar Pembelajaran. Jakarta: PRENAMEDIA GROUP.

Wibawa, B. dan Mukti, F. (2001). Media Pengajaran. Bandung: CV Maulana.

Wiriaatmadja, R. (2010). Metode Penelitian Tindakan Kelas Untuk Meningkatkan Kinerja Guru dan Dosen (nine ed). Bandung: PT. Remaja Rosdakarya.

Wiyani, A. N. (2013). Manajemen Kelas Teori dan Aplikasi Untuk Menciptakan Kelas yang Kondusif. Yogyakarta: AR-Ruzz Media. 